\title{
How do Convenience Ingredients Encourage Young Generations to Preserve the Malay Traditional Food Practice?
}

Mohd. Shazali Md. Sharif, Mohd. Zain Kutut, Mohd Salehuddin Mohd Zahari, Noriza Ishak, Rosmaliza Mohammad

To Link this Article: http://dx.doi.org/10.6007/IJARBSS/v11-i13/8512

DOI:10.6007/IJARBSS/v11-i13/8512

Received: 10 November 2020, Revised: 13 December 2020, Accepted: 31 December 2020

Published Online: 25 January 2021

In-Text Citation: (Sharif et al., 2021)

To Cite this Article: Sharif, M. S. M., Kutut, M. Z., Zahari, M. S. M., Ishak, N., \& Mohammad, R. (2021). How do Convenience Ingredients Encourage Young Generations to Preserve the Malay Traditional Food Practice? International Journal of Academic Research in Business and Social Sciences, 11(13), 148-159.

Copyright: (c) 2021 The Author(s)

Published by Human Resource Management Academic Research Society (www.hrmars.com) This article is published under the Creative Commons Attribution (CC BY 4.0) license. Anyone may reproduce, distribute, translate and create derivative works of this article (for both commercial and non-commercial purposes), subject to full attribution to the original publication and authors. The full terms of this license may be seen at: http://creativecommons.org/licences/by/4.0/legalcode

Special Issue: Beyond 2021 and COVID-19 - New Perspective in the Hospitality \& Tourism Industry, 2021, Pg. 148 - 159 


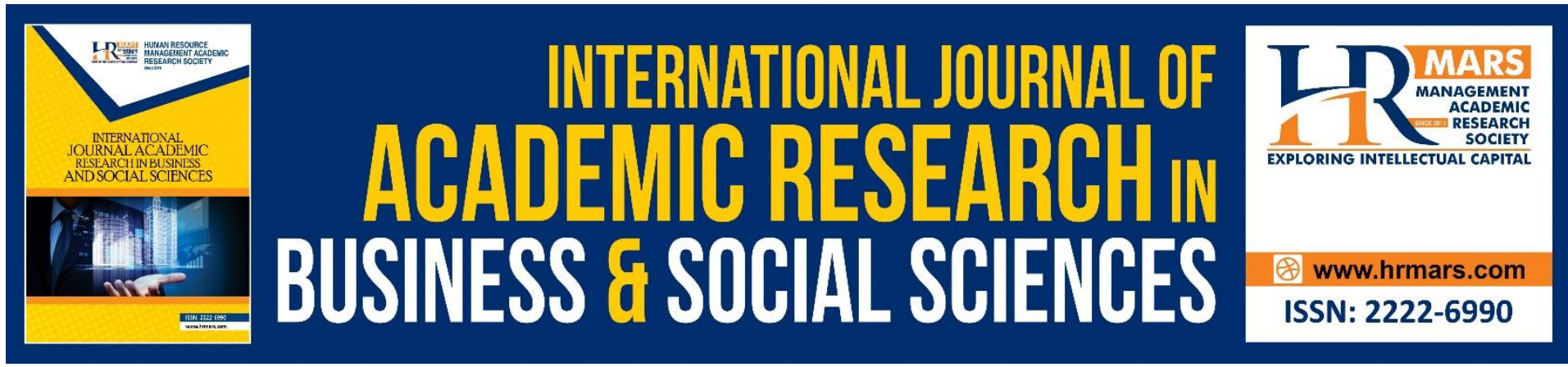

\title{
How do Convenience Ingredients Encourage Young Generations to Preserve the Malay Traditional Food Practice?
}

\author{
Mohd. Shazali Md. Sharif, Mohd. Zain Kutut, Mohd Salehuddin \\ Mohd Zahari, Noriza Ishak, Rosmaliza Mohammad \\ Faculty of Hotel and Tourism Management, Universiti Teknologi MARA Kampus Puncak \\ Alam, Selangor, Malaysia
}

\begin{abstract}
Convenience ingredients are products designed for easiness. It helps the communities to adapt in this modern era. There are many convenience products being used in Malay dishes and the users are increasing. This indicates that Malay users have realized the benefits of them. This study aimed to acknowledge the use of convenience ingredients and determine the future utilization of convenience ingredients in Malay traditional dishes. This study attempted to verify the factors that influence the use of convenience ingredients by youngsters and at the same time identify the benefits that can be obtained when adapting the ingredients into the traditional dishes. Ethnographic method was adapted in this study that applied observation and picture taking techniques to achieve the targeted objectives. This enabled the researchers to gain valid information. The crucial element identified in the findings was that the complicated processes of producing the traditional dishes have been simplified. By using convenience products, they were able to avoid any complicated process. Time saving was the second element that can be found as foods can be prepared in a short time. The urban area was the third element as many youngsters are living in urban areas where access to get the original ingredients is limited. Lastly, Malay traditional food should be passed down to youngsters to retain the tradition. This can be done with the use of convenience foods. Although the uses of convenience ingredients are replacing the original ingredients, it still preserves the traditional food practices.
\end{abstract}

Keywords: Convenience Foods, Food Practices, Young Generation, Malay Traditional Food.

\section{Introduction}

Malays have their typical foods when it comes to traditional dishes. This typical food is a tradition practice that must be carried and preserved so that it would not be forgotten and vanished in the future generation. Most of the young generations nowadays have busy careers that restrict them from learning and practice the Malay food tradition which lead to the distinction of one of the Malay identities. It is a concerned that the knowledge of the traditional 
foods might be gone and difficult to reform. In contrary, young generations nowadays claim to face many barriers to continue the tradition properly and effectively. Many companies have come out with innovations so that the tradition can be continued that suits the new generation. The industry and service sectors have readily reacted to the convenience trend by stepping up product development and expanding their offer of convenience products and services (Costa et al., 2007). The process of learning mostly comes directly from the parents. This study attempted to determine and identify whether the approach of convenience ingredients can help and enhance the young generation to preserve the Malay traditional food traditional products, which have been practiced since long time ago.

The main objective of this study is to acknowledge the use of convenience ingredients in Malay traditional dishes. This study showed how Malay traditional dishes revolved in terms of ingredients from the ancestors to the current generation. Besides that, this study also proved that convenience ingredients are parts of main ingredients in producing Malay traditional dishes especially within the younger generation. Malay traditional dishes have been proven a combination of recipes inherited from ancestors with the usage of convenient foods in this modern life. Secondly, it is to determine the future utilization of convenience ingredients in Malay traditional dishes. By this means, the society is able to experiment with convenience ingredients that are available in the market to make Malay traditional dishes more frequent and efficient. This will produce another innovation in convenience ingredients through ingredient modification. This study also attempted to verify the factors that influence the uses of convenience ingredients by the youngsters in producing the traditional dishes. These youngsters are individuals that will give knowledge through food practice to the next generation. This study also showed how youngsters prefer to use convenient foods than original foods. Finally, the study identified the benefits that can be obtained when adapting the ingredients into the traditional dishes. The findings described the benefits of using convenience foods.

\section{Literature Review}

Traditional is frequently associated with activities or products that reflect the older generation practices who might be the first inventor or creator of the products and activities (Kwik, 2008). On the other hand, traditional food refers to food that has been consumed by many generations which included all indigenous food plants found in that region or in a specific locality (European Union, 2007). Trichopoulou, Soukara and Vasilopoulou (2007) pronounced traditional food as an expression of one's culture, history and lifestyle that reflects the cultural heritage and leaves their prints to contemporary dietary patterns to the subsequent generation. This is to represent on how the communities enjoy their foods. Those foods are associated with meanings, symbols and expressions and they are recognized as the integrative force that enhances solidarity and alliances between individuals and kin groups (Quah, 2008).

According to Oxford Dictionary, convenience is defined as the state of being able to proceed with something without difficulty. Food product is a substance that can be used or prepared for use as food. Therefore, convenience food products are the results of foods that have been prepared by using ready-made or packaged substances. Costa et al. (2007) deduced that the convenient determines where, when, why, what, how, and with whom we eat. Many agreed that convenience is all about time and effort saving (Buckley et al., 2007). By using these 
convenience foods, the time taken to make a single meal will decrease and this applied efficiently to most career busy women. Efforts include mental and physical effort, consisting of thought and energy production activities physically involved in the process of food preparation (Candel, 2001). This trend started from the Western world where consumers demand for convenience ingredients is increasing around the world. Increased presence of drive-through, microwave meals, take-out food, home delivery service for groceries and even internet shopping have demonstrated the importance of convenience in the choices and preparation of foods (Jaeger \& Meiselman, 2004). Many individuals have argued on convenience ingredients which are an impediment to achieving a healthy and balanced diet that includes fruits and vegetables (Jaeger \& Cardello, 2007). Involvement is another effect due to the orientation of convenience food. Ryan, Cowan, McCarthy and O'sullivan (2002) found that the type of person who is 'extremely uninvolved' would more often buy simple food products such as frozen vegetables.

A large number of studies have been conducted in different countries on consumers which relate to consumer income. A study by Gallup, Sachs, Mellinger (1999) stated that 37 percent of Danish buys organic food when they shop. This showed that they have strong economic income since organic food is quite expensive. People nowadays realized it is worth to spend money on food as it satisfies them. According to Yin et al. (2010), most Chinese consumers prefer to buy organic food due to their income, degree of trust in consuming organic food, the acceptance of organic food and degree of concern in health. This also indicates people with higher income are changing their food habits towards a more environmental-friendly condition (Halkier, 2001). A study in Australia found that subjects that have low socioeconomic groups are less likely to buy food in accordance with national dietary guidelines (Turrel, 2004). In contrast, the relationship between price and demand showed the situation of unhealthy food product which is more costly than healthier food and this will increase the consumption of healthy foods (Epstein, 2006). Socio-economic status could be one of the factors that relate to the different consumption of fruits and vegetables among youth (Jago, Baranowski, Baranowski, Cullen \& Thompson, 2007). A study has shown that price changes especially when it elevates the influence to purchase healthy food products that are available in vending machines, canteen and restaurants. Level of economy is also related to food insecurity. This is probably due to geographic factors or facilities that limit people to access food. Some countries like Canada are able to identify how to make food insecurity become less among consumers. These include ensuring all healthy food is accessible (Roberts, 2011).

Social influence is one of the main factors that can determine a person's dietary pattern. As described by Mollen et al (2013), the behaviour of others in people's social environment (i.e., descriptive norms), as well as their opinions regarding appropriate actions (i.e., injunctive norms) strongly influence people's decisions and actions. These authors emphasized that social culture helps to shape someone's action. Social transition and unlimited information technology are believed to influence the changes of food intake and practices (Nor et al., 2012).

Social influence in food practice is especially important as it plays a key role in shaping up an individual's daily diet and it can lead to a healthy or unhealthy diet. There are many types of social influences such as parents, peers or the society. The large contributor in building up someone's daily diet is parent. The use of food-related parenting practices such as pressuring 
children to eat and restricting children's intake are believed to have a harmful impact on children's current and future dietary intake since this encouragement overrides children's innate, internal hunger and satiety cues (Loth et al., 2013). Marriage/cohabitation emerged as a turning point in some men's eating habits since some seemed to enter this union with their own unique food preferences, which often differ to their partners (Newcombe et al., 2012; Nor et al., 2012). From Fonte's (2013) point of view, the dietary pattern nowadays is at risk as there are many negative influences in the society.

\section{Methodology}

The use of convenience ingredients in Malay traditional dishes among young generation is studied using qualitative method to investigate the effect of the practice on the young generation. This method was chosen in this research because the results will show more details in the reason the younger generation prefer to use convenience ingredients in preparing Malay traditional dishes. Qualitative research methods are well suited for addressing such gaps in our knowledge (Weiner et al., 2011). In this research, it focused more on ethnographic method and observation. Engaging with participants using qualitative methods highlights the range of risks they face and enables evaluators to face ethical issues with the seriousness and sincerity they deserve (Prowse \& Camfield, 2012). Qualitative method, or more specific ethnographic method, is used to discover the uses of convenience ingredients in preparing Malay traditional dishes among Malay younger generation. The sample population was among 4 families that have both generations. All the subjects lived in urban areas. For the woman with older age, the range of age was between 50 to 70 years old. As for the young generation, the age range for the chosen women was between 15 to 25 years old. To obtain information and their experience, short interview was conducted between the researchers and focus group.

Each family has different opinion and reason in the uses of convenience foods. This research only focused on the women between two generations in one family. Owing to the enormous of two generations (mothers with married daughters) in a family unit, the researcher had identified that it was difficult to cater the desired information throughout the entire group in this region with limited time (Nor et al., 2012). Due to time and money limitation, it is impossible for the researchers to conduct a survey on the entire population. With large population size, it is difficult for the researchers to study every element in the population. Focus groups have been used for a range of purposes and in various contexts by academic and applied researchers (George, 2012). This statement shows that due to restriction in studying the whole population, most of the researchers chose to study focus group.

As for the instrument in this research, the researchers used a camera to collect the data. Pictures were used to study the insight of the young generation in what influences them to use convenience ingredients when preparing Malay traditional dishes. Questionnaire was not used in this research because the focus group involved old women and some of them had difficulty in reading. Moreover, more information can be obtained by interviewing them. The main tools in this research were interview

and pictures. In the observation process, the researchers only observed without being directly involved 
in it. Notes were taken along the observation process to tap on the important points and behaviour. Pictures were taken as data in the study as evidence. Based on this study, the researchers found that the uses of convenience food products were able to avoid complicated processes during food preparation.

\section{Result and Analysis \\ Convenience Ingredients Solves Complicated Processes in Malay Traditional Foods Productions}

Nowadays, numerous numbers of people consume a wide range of convenience foods. Since these convenience ingredients are ready to eat when it is bought, some do think that this inclination leads to a complete replacement of natural food with equivalent one. Convenience ingredients somehow have become increasingly common and eventually replacing traditional foods and the traditional method for foods preparation. Convenience ingredients are useful for the people in this century since it cuts down the time for food preparation. By using this type of foods, it can shorten the time to produce the traditional dishes. For example, in the production of rendang, there are many rendang paste available nowadays in the market where it only needs the cook to just add coconut cream, meat item, fresh herbs and kerisik. Convenience ingredients also reduce planning, buying and storing of ingredients. For instant, to make kerisik, we must buy the grated coconut and cook it until it becomes dry and yellowish. After that, we have to put the dry coconut in a pestle or mortar to release its fragrance and oil. These whole processes require time, labour intensive and complicated processes. By using ready-made kerisik, it overcomes those issues and fastens the production of rendang. Convenience ingredients are also faster and easy to clean up since most of they are in packaging, canned or packets. Once we use it, we can just throw the packaging away. This saves time to clean up the kitchen and it is easy. The availability of convenience ingredients is easy to access since it is found everywhere. For those who live in urban place, it is hard to find fresh grated coconut to make kerisik; therefore, the convenience ingredients like kerisik might help. Convenience ingredients really help in avoiding the hustle and bustle in producing the Malay traditional dishes.
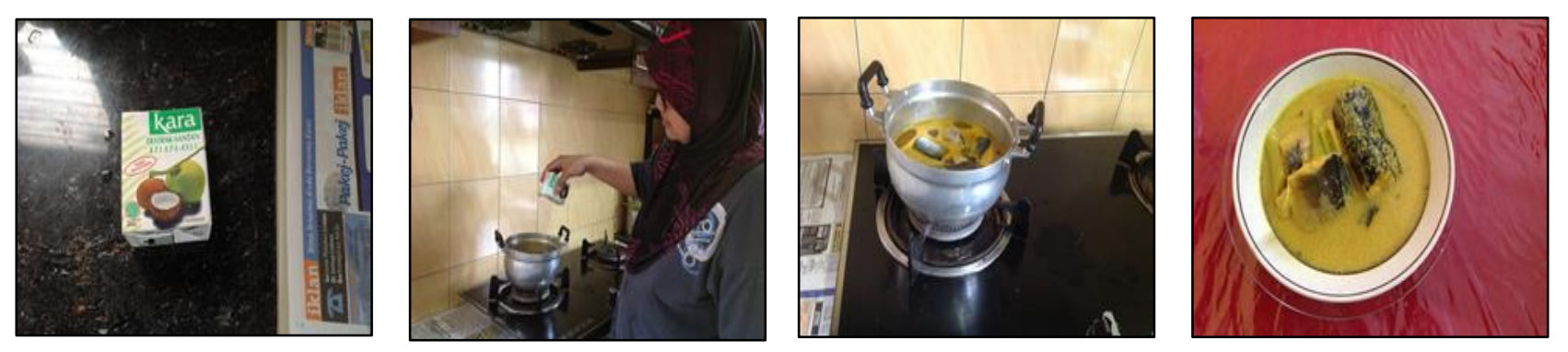

Figure 1: Demonstrates the use of coconut cream in making gulai ikan where it reduces the hustle of grating and squeezing the coconut to get its cream

\section{Convenience Ingredients Encourage the Young Generation to Practice the Malay Traditional Foods}

Time restriction is an excuse always given by the young generation nowadays for not practicing Malay traditional foods. Based on the observation, Malay traditional foods are unique and complicated as the ingredients usually consist of raw substances and involve many 
processes to maintain the authentic and originality taste of the food. The process of preparing Malay traditional foods starts from

buying the ingredients, preparing the ingredients, cooking and lastly serving the dishes. Therefore, the

time taken to complete a single Malay traditional dish acquires one to two hours. This scenario has given a nightmare to the individual who wants to cook the traditional dishes especially to younger generation who give more priority to their career. One of the ways to save time and energy is by using convenience ingredients. Nowadays, there are many convenience ingredients available in the market where the products ease or cut short the process of producing Malay traditional foods. Some of the convenience ingredients are blended chilies, coconut cream, cooking paste, slice beef, cut chicken, tamarind paste and many others. All these convenience ingredients support the new generation in practicing the Malay traditional dishes due to the simplicity and suitability offered by the convenience ingredients. Most significant motivation with the availability of convenience ingredients, it has made the cooking process shorter and the kitchen less messy due to less preparation before performing the cooking.
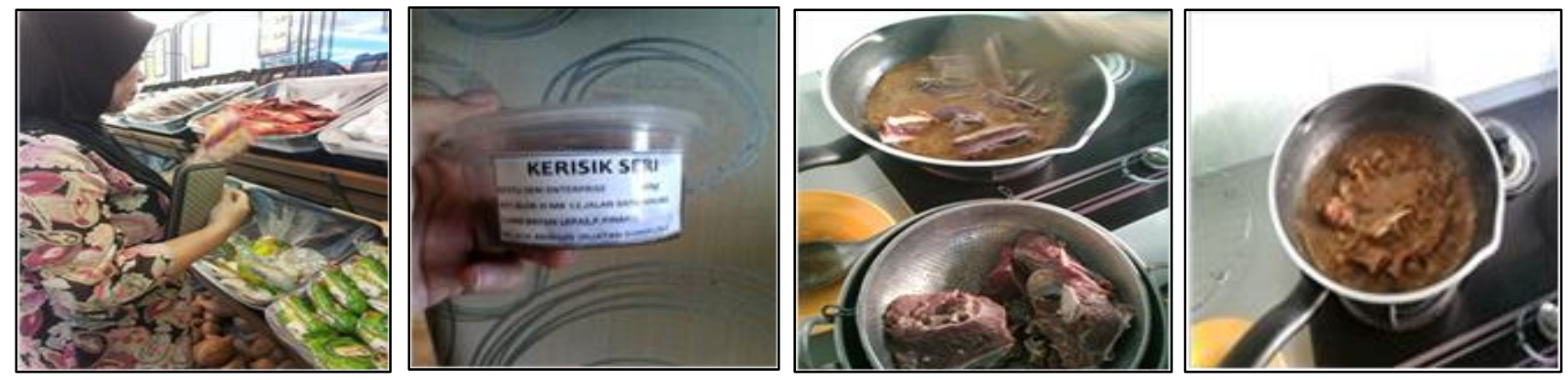

Figure 2: The use of kerisik in making one of the traditional dishes. It took one hour if we produce kerisik manually

\section{Convenience Ingredients Replace the Original Ingredients That Are Difficult to Find in Urban Area}

Nowadays, convenience ingredients are widely used especially in urban areas. Urban community prefers to use convenience food because it is accessible anytime and anywhere with huge array of innovation in food products. For some original foods, they are more costly compared to when purchasing convenience ingredients like anchovies paste. The anchovies are more expensive than the paste. Hence, it is no surprise there are many types of paste and flavour that suit the appetite of the consumers. Besides paste and flavour, convenience food gives the consumers ideas on how they can modify their dish and food preparation. For instance, in Figure 3(a), the usage of tomato puree in packaging is used rather than making tomato puree from the scratch. The key-point is it saves time and more efficient. It is more applicable just to buy a can of tomato puree from the supermarket in a few minutes rather than buying tomatoes and cooking them in stove for few hours to make the puree. Figure 3 (b) proves that it can be used straight to the pan unlike the original paste which needs to be cooked before putting it in pan when cooking the main dish. Thus, it becomes easier to do kitchen clean up later. Compared to the original tomato puree, we need to clean the pan and blender. This is quite annoying for people who live in a fast-paced life. 


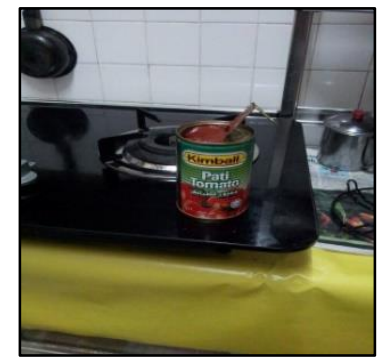

Figure 3a

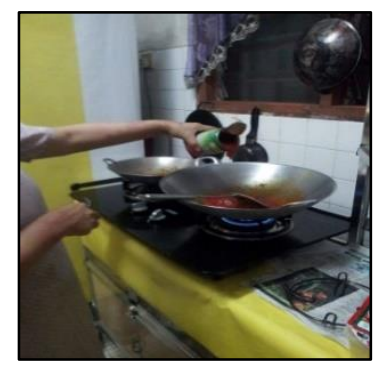

Figure $3 b$

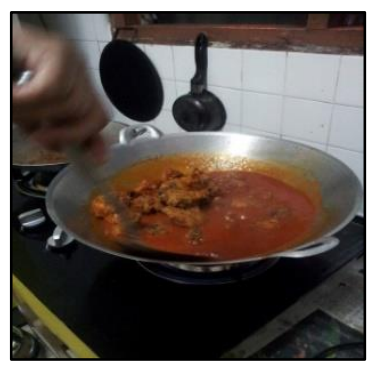

Figure 3c

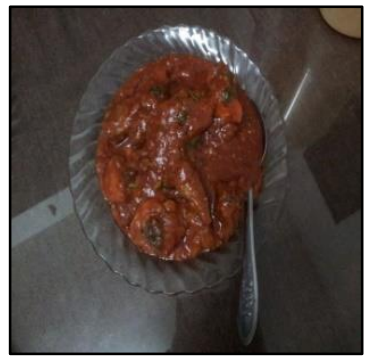

Figure 3d

In addition, most convenience food retains the original texture like in Figure 3 (c). The paste still gives its gravy though it is less viscous than the original tomato puree. Based on this figure, the process for the food preparation of dish is still the same as the cooking using original foods. Moreover, the cooking time is almost the same as using the original foods. In Figure 3 (d), it shows the outcome of using convenience foods. The aroma, texture, taste and appearance are more likely similar as in using original foods. Therefore, convenience food helps people in urban areas to put their creativity on how they can use other ingredients instead of the original that is unavailable in their area. In addition, they still keep the authenticity of the dish.

\section{Convenience Ingredients Provide Cooking Guidelines}

Convenience ingredients are products made to give accommodations to those persons who have barriers in using original ingredients in preparing dishes. In this modern era, some women are also studying and working. These women do not have enough chances to learn the preparation of Malay traditional dishes from their mothers. Although they can go back home during the semester break, they are always occupied in handling other matters such as research, assignment etc. Not all of them are interested in cooking lesson. Some prefer to engage in outdoor activities. Therefore, the young generation specifically women will not have enough knowledge and skills in the kitchen. This will become obstacle for them as they have a huge responsibility in the future which is to preserve the Malay traditional dishes. This is where convenience ingredients play an important role. In this fast-moving era, people are more open in the usage of convenience foods.

Now people have already accepted the facts that it is impossible to find all the original ingredients needed due to time and money limitations. That is why the young generation prefers to use convenience ingredients as the packaging usually provides instructions on how to prepare the dishes. As seen in Picture 4(a), the package of the convenience food has instructions written on it. They can read the instructions and cook the dishes. It only needs little time for this book-smart generation to learn how to cook. As seen in Picture 4(b), the subject just follows the instructions given to cook the dishes. Convenience ingredients help the young generation to prepare their traditional dishes properly as they can find the cooking guidelines on convenience food's packaging. This can help the young generation to preserve the original Malay traditional dishes. 


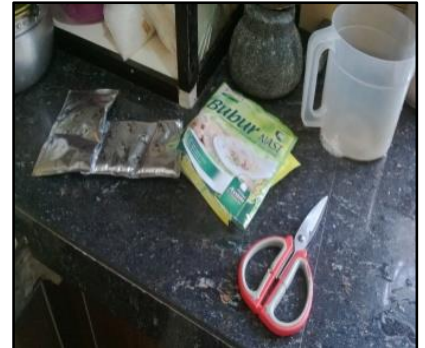

Figure $4 a$

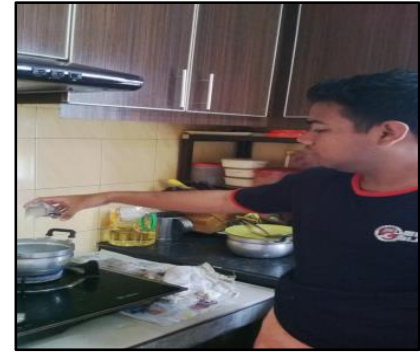

Figure $4 b$

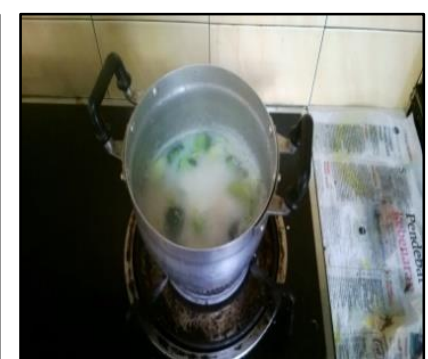

Figure 4c

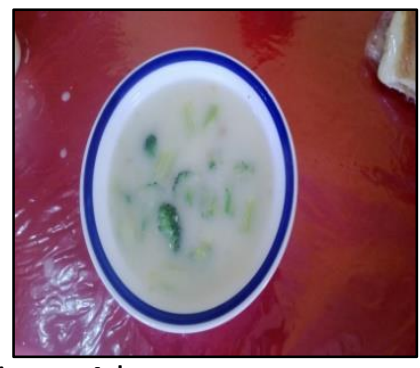

Figure 4d

Convenience Ingredients Reassure the Youngsters to Preserve Their Traditional Dishes Nowadays, convenience ingredients have become part of the society. Convenience ingredients are made to ease people's lives. At the early age of convenience ingredients production, many people are sceptical about it due to its ingredients containing chemical substances. People are afraid that the intake of convenience ingredients will have adverse effects to their health. In this modern era where even women have to study and work, they must find an alternative way to simplify the cooking process of Malay traditional dishes. This is because they cannot follow the traditional ways in preparing the dishes due to time limitation. They are also not able to obtain all the original ingredients especially for those who live in the urban area. Due to all these limitations, the traditional Malay traditional dishes may face extinction.

Convenience ingredients are the best alternative to this problem. These pre-made products resemble the original ingredients that are needed in preparing traditional Malay dishes. Nowadays, the acceptance of people towards convenience ingredients is increasing as they realize they cannot follow their ancestor's ways. Convenience ingredients help to overcome some problems that have become the extinction factors of traditional Malay traditional dishes. These products help the users to replace some of the ingredients that cannot be found in the urban areas. These show how convenience ingredients help to overcome all the problems in preserving traditional dishes. Convenience ingredients help the youngsters to preserve their traditional dishes.
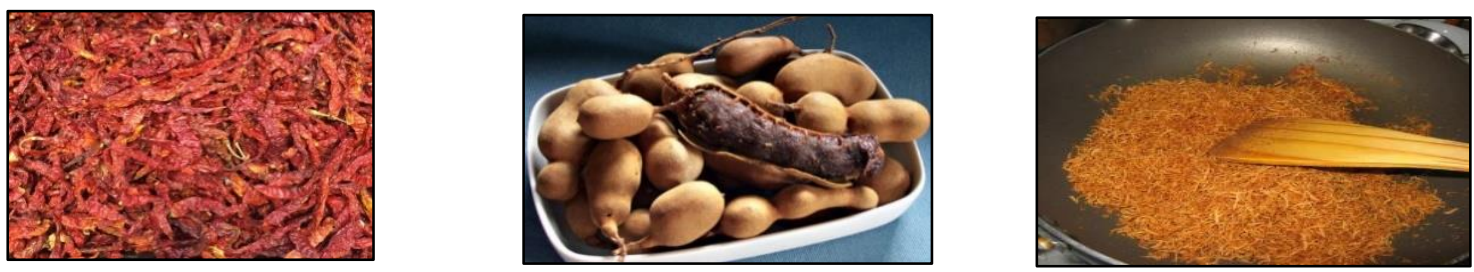

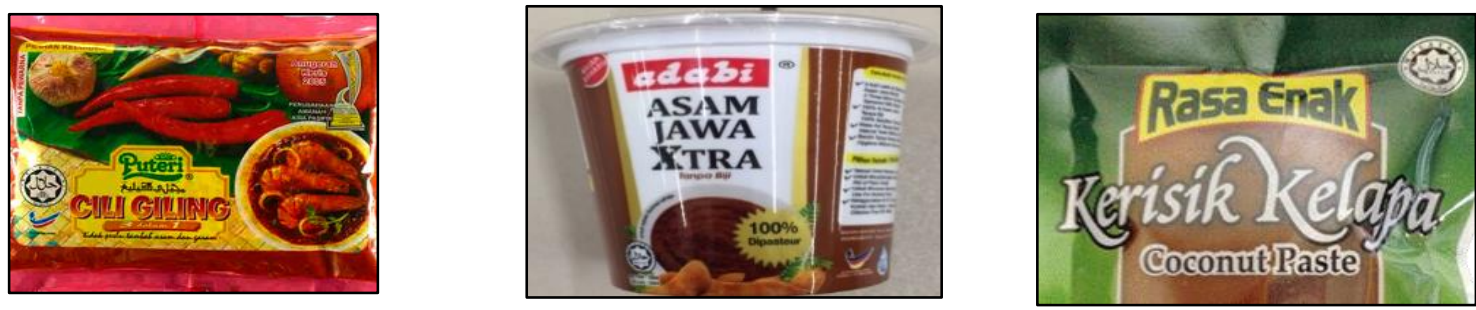

Figure 5: The three pictures on the top row are traditional Malay food ingredients in their original form. The three ingredients at the bottom row are the same ingredients but in a processed and convenient form

\section{Discussion}

Convenience food does help the young generation to motivate and preserve the Malay traditional dishes. Even though the convenience ingredients itself is an evolution of food industry that replaces the originality of traditional foods, it has made easier for the young generation to maintain it since the convenience ingredients helps to shorten the cooking time and the food preparation time. Furthermore, it creates the kitchen to always look tidy and organized due to less preparation before cooking is performed. Convenience ingredients help to avoid all the long and complicated process in making the Malay traditional dishes. Besides, with the help of these convenience ingredients, it saves time and able to produce more dishes in a short time. Somehow, these factors will encourage the youngsters to keep on cooking and practice the Malay traditional dishes even though they are busy with their daily career routine. Convenience ingredients also give the youngsters no reasons for not to practice their traditional dishes because it is easily available in the market.

Those who live in the urban area, convenience ingredients help to replace the original ingredients that are difficult to find in their living society. Convenience ingredients help the young generation to prepare their traditional dishes properly as it provides the step-by-step cooking method on almost each packaging which would make the youngsters love to cook because everything is provided. Other than that, parents also play a vital role. The parents should always encourage their children to learn and practice their family traditional dishes so that it can be carried on to the future generation. Without encouragement and efforts from the parents, the young generation would not be able to practice their own traditional dishes even though there are many convenience ingredients available in the market. There are many advantages of convenience ingredients usage in preserving Malay traditional foods, but more exposure and promotion need to be conducted by manufacturer and community to establish the easiness of convenience ingredients by assisting them in practicing the Malay traditional dishes.

\section{Conclusion}

In conclusion, regular practice and understanding sharing through communication are the key features in determining the sustainability of the Malay traditional food for future generation. Youngsters prefer to use convenient food products during the preparation of food on special occasion as it is more efficient. Malay traditional food should be passed down to the younger generation with the new innovations to retain the tradition. As a conclusion, convenience 
ingredients can help the young generation to preserve the Malay traditional food products. The most important part is the parents should play a significant role in encouraging their children to absorb and practice the family traditional dishes so that it can be carried on to the future generation. Without reinforcement and hard work from the parents, the young generation will not be aware and able to practice and pass down their own traditional dishes that symbolize their ethnic identity.

\section{Corresponding Author}

Mohd. Shazali Md. Sharif. Faculty of Hotel and Tourism Management, Universiti Teknologi MARA Selangor, Puncak Alam Campus, Selangor.

Email: shazali@uitm.edu.my

\section{References}

Candel, M. J. (2001). Consumers' convenience orientation towards meal preparation: conceptualization and measurement. Appetite, 36(1), 15-28.

Costa, A. I., Schoolmeester, D., Dekker, M., \& Jongen, W. M. F. (2007). To cook or not to cook: A means-end study of motives for choice of meal solutions. Food Quality and Preference, 18(1), 77-88.

European Union. (2007). European Research on Traditional Foods. Belgium: Publications.europa.eu

Fonte, M. (2013). Food consumption as social practice: Solidarity purchasing groups in Rome, Italy. Journal of Rural Studies, 32, 230-239.

Gallup, Sachs, Mellinger (1999). Geography and Economic Development. International Regional Science Review, 22(2), 179-232.

George, M. (2012). Teaching Focus Group Interviewing: Benefits and Challenges. Teaching Sociology, 41(3), 257-270. https://doi.org/10.1177/0092055X12465295

Halkier, B. (2001). Consuming ambivalences: consumer handling of environmentally related risks in food. Journal of consumer culture, 1(2), 205-224.

Jaeger, S. R., \& Cardello, A. V. (2007). A construct analysis of meal convenience applied to military foods. Appetite, 49(1), 231-239.

Jaeger, S. R., \& Meiselman, H. L. (2004). Perceptions of meal convenience: The case of athome evening meals. Appetite, 42(3), 317-325.

Jago, R., Baranowski, T., Baranowski, J. C., Cullen, K. W., \& Thompson, D. (2007). Distance to food stores $\&$ adolescent male fruit and vegetable consumption: mediation effects, 10 , 1-10. https://doi.org/10.1186/1479-Received

Kwik, J. C. (2008). Traditional food knowledge: A case study of an Immigrant Canadian "foodscape". Environments, 36(1), 59-74.

Loth, K. A., MacLehose, R. F., Fulkerson, J. A., Crow, S., \& Neumark-Sztainer, D. (2013). Foodrelated parenting practices and adolescent weight status: a population-based study. Pediatrics, 131(5), e1443-e1450.

Mollen, S., Rimal, R. N., Ruiter, R. A. C., \& Kok, G. (2013). Healthy and unhealthy social norms and food selection. Findings from a field-experiment. Appetite, 65, 83-9. https://doi.org/10.1016/j.appet.2013.01.020

Newcombe, M. A., McCarthy, M. B., Cronin, J. M., \& McCarthy, S. N. (2012). "Eat like a man". A social constructionist analysis of the role of food in men's lives. Appetite, 59(2), 391398. 
Nor, N. M., Sharif, M. S. M., Zahari, M. S. M., Salleh, H. M., Isha, N., \& Muhammad, R. (2012). The Transmission Modes of Malay Traditional Food Knowledge within Generations. Procedia - Social and Behavioral Sciences, 50(July), 79-88. https://doi.org/10.1016/j.sbspro.2012.08.017

Prowse, M., \& Camfield, L. (2012). Improving the quality of development assistance: What role for qualitative methods in randomized experiments? Progress in Development Studies, 13(1), 51-61. https://doi.org/10.1177/146499341201300104

Quah, S. R. (2008). Home and Kin: Families in Asia. Singapore: Times Academic Press

Ryan, I., Cowan, C., McCarthy, M., \& O'sullivan, C. (2004). Food-related lifestyle segments in Ireland with a convenience orientation. Journal of International Food \& Agribusiness Marketing, 14(4), 29-47.

Roberts, K. T. (2011). The physiological and rheological effects of foods supplemented with guar gum. Food Research International, 44(5), 1109-1114.

Trichopoulou, A., Soukara, S., \& Vasilopoulou, E. (2007). Traditional Foods: A Science and Society Perspective. Trends in Food Science \& Technology, 18(8), 420-427.

Turrell, G. (2004). A multilevel analysis of socioeconomic (small area) differences in household food purchasing behaviour. Journal of Epidemiology \& Community Health, 58(3), 208215. https://doi.org/10.1136/jech.2003.011031

Weiner, B. J., Amick, H. R., Lund, J. L., Lee, S.-Y. D., \& Hoff, T. J. (2011). Use of qualitative methods in published health services and management research: a 10-year review. Medical care research and review: MCRR, 68(1), 3-33. https://doi.org/10.1177/1077558710372810

Yin, S., Wu, L., Du, L., \& Chen, M. (2010). Consumers' purchase intention of organic food in China. Journal of the science of food and agriculture, 90(8), 1361-7. https://doi.org/10.1002/jsfa.3936 